Vale da Silva, Felipe. - Werther à luz da história do conceito de subjetividade

\title{
Die Leiden des jungen Werthers à luz da história do conceito de subjetividade
}

[The sorrows of Young Werther in the light of the concept of subjectivity]

Felipe Vale da Silva ${ }^{1}$

\begin{abstract}
This article analyses the parallels between, on the one hand, the portrayal of the 'struggling modern subject' depicted by Goethe in his Die Leiden des jungen Werthers and, on the other, the psychosocial profile of the 'sentimental man' from the $18^{\text {th }}$ century, product of the cultural environment of the Empfindsamkeit. I argue that in this novel, in borrowing the Empfindsamkeit's most traditional literary genre - the epistolary novel —, Goethe ends up mimicking a number of topoi and discursive techniques proper to this tradition, though in a radically heterodox fashion. The approach will lead us to a deduction of Goethe's own views on the modern subject, which situates him as an important figure within the discourse of modernity.
\end{abstract}

Keywords: Sentimentalism - Goethe - subjectivity - modernity - epistolary novel

Resumo: O artigo analisa os paralelos entre o retrato do 'sujeito moderno em crise' visto no romance Die Leiden des jungen Werthers de Goethe e, por outro lado, o perfil psicossocial do 'homem do sentimento' do século XVIII, fruto da cultura da Empfindsamkeit. Defendo a perspectiva de que, no romance, Goethe não apenas se utiliza do formato literário mais tradicional da Empfindsamkeit (o do romance epistolar), como também se apropria de topói e técnicas discursivas que lhe são próprias em registro radicalmente heterodoxo. A argumentação nos ligará a uma dedução da visão do conceito de subjetividade moderna com que Goethe trabalha em sua fase final do Sturm und Drang, e que o situa como importante nome do discurso filosófico da modernidade.

Palavras-chave: Sentimentalismo - Goethe - subjetividade - modernidade - romance epistolar

\footnotetext{
${ }^{1}$ Felipe Vale da Silva possui mestrado em Literatura Alemã pela Universidade de São Paulo. E-mail: felipe.vale.silva@usp.br. O presente artigo retoma e resume as reflexões feitas nos capítulos 1.1, 1.4 e em toda parte 2 de minha dissertação de mestrado, "Subjetividade e Experiência em Die Leiden des jungen Werthers e Wilhelm Meisters theatralische Sendung de J. W. Goethe", apresentada em 2012 na Universidade de São Paulo. Cf. Referências Bibliográficas.
} 
Vale da Silva, Felipe. - Werther à luz da história do conceito de subjetividade

\section{A subjetividade na literatura: notas preliminares}

Goethe publicou seu primeiro romance, Die Leiden des jungen Werthers ${ }^{2}$, em 1774, e já no mesmo ano, em uma resenha escrita por Christian Friedrich BLANCKENBURG, nos deparamos com uma formulação ainda bastante familiar para o leitor contemporâneo do cânone europeu: o resenhista resume Werther a uma obra em que „der Dichter wollte uns [...] die innre Geschichte eines Mannes geben". ${ }^{3}$ Para Blanckenburg, este não é somente um óbvio aspecto formal do romance, como também seu diferencial dentro da tradição literária 'séria' de seu país. ${ }^{4}$ Ao reduzir a obra a seu peculiar foco na interioridade de um indivíduo, Blanckenburg termina por contar como apenas o primeiro nome dentre um vasto rol de críticos que, ao se verem na necessidade de justificar a relevância de Werther dentro do cânone do século XVIII, enfatizam a obra como iniciadora icônica de uma cultura literária do individualismo na Alemanha. ${ }^{5}$

Nesta mesma chave, Ruth-Ellen JOERES (2003: 207), no recente Cambridge History of German Literature, caracterizará o livro como "um produto da Geração do $\mathrm{Eu},[\mathrm{d}] \mathrm{o}$ interesse crescente no ego individual [sic!], [...] no Genie que se tornou a focalização para os jovens escritores masculinos do Sturm und Drang”. Thomas MANN, em sua famosa formulação, evitará falar do romance em questão como pioneiro da literatura focada em temas subjetivos, ainda que o eleja como representante exemplar da cultura da Innerlichkeit de sua época, cujo protagonista se revela na condição de "ein Meister unbarmherziger Introspektion, Selbstbeobachtung, Selbstzergliederung - das

\footnotetext{
${ }^{2}$ Mencionarei, a partir de agora, o romance Die Leiden des jungen Werthers somente como Werther, em itálico. Citações da obra serão feitas com base na edição da Deutscher Klassiker Verlag (GOETHE, Johann Wolfgang. Die Leiden des jungen Werthers - Die Wahlverwandtschaften - Kleine Prosa - Epen (Hrsg. von Waltraud Wiethölten). Frankfurt am Main: Deutscher Klassiker Verlag, 2006), e suas traduções colocadas em notas de rodapé, com base na tradução de Marcelo Backes (GOETHE, Johann Wolfgang. Os Sofrimentos do Jovem Werther (trad. Marcelo Backes). Porto Alegre: L\&PM Editores, 2001). Referências ao protagonista do romance serão, por fim, feitas em fonte não-italicizada.

${ }^{3}$ BLANCKENBURG (1774 [1981]: 394). "O poeta quis nos dar a história interior de um homem" (grifo do autor, tradução minha).

${ }^{4}$ Isto é, que Blanckenburg considerava artisticamente válida. Cf. JOERES (2003: 212s).

${ }^{5}$ As referências são inúmeras; de fato referências de críticas que não iniciam um tratamento do romance nesta chave constituem uma exceção. Ver o vasto balanço de posicionamentos mais pontuais da fortuna crítica da obra em BLACKALL (1976: 280-283).
} 
Vale da Silva, Felipe. - Werther à luz da história do conceito de subjetividade

überfeinerte Endprodukt christlich-pietistischer Seelenkultur."6 (MANN (1939 [1960]: 649).

A formulação de Mann soa, no contexto argumentativo deste trabalho, mais correta por considerar que Goethe não inaugura o uso da ficção com a finalidade de exploração psicológica da condição humana, da existência do homem enquanto sujeito autônomo e isolado - exploração, enfim, daquilo que comumente chamamos "subjetividade moderna". É mais correto dizer que a exploração psicológica da interioridade na literatura começa, especificamente na Alemanha, não na década de 1770, mas cerca de meio século antes disso, com os romances confessionais pietistas (cf. VAN DÜLMEN 2005: 132). O que torna Werther diferente de seus antecedentes - o que lhe confere o "refinamento" do qual fala Mann - permanece uma questão ainda aberta a comentários.

Sem ter sido suficientemente elucidada, a questão levantada por Thomas Mann em seu mencionado discurso de 1939 é geralmente justificada pela crítica goethiana recorrendo-se ao contexto sócio-histórico paradigmático no qual a obra do jovem Goethe foi gerada. O período em que o autor escreve seus romances iniciais - décadas de 1770 e 1780 - é marcado por uma ampliação sem precedentes das liberdades individuais do homem comum. Dentre elas, podemos citar a possibilidade inédita de o homem ordinário ter acesso a uma educação formal, optar por carreiras profissionais diferentes daquelas de seus antepassados, mover-se geograficamente e participar de uma esfera pública que então se formava. Tal processo é acompanhado de uma renovação das dinâmicas de socialização - passa-se a falar de isolamento e alienação da vida urbana -, surgem, além disso, uma série de códigos culturais articuladores de uma compreensão renovada do valor e possibilidades de atuação individual do ser humano. Nasce a 'subjetividade moderna' - e a importância de um romance como Werther para a história da literatura alemã é comumente explicada, assim, com base em seu sucesso em retratar um estado de coisas ainda novo, informulado, expressivo da existência de indivíduos em sua época. É assim que podemos identificar no romance de Goethe um documento de uma crise epistêmica dos saberes acerca da vida humana, em chave

\footnotetext{
6 “um mestre da introspecção impiedosa, da observação e análise de si - refinado produto final da cultura da espiritualidade cristã-pietista" (tradução minha).
} 
Vale da Silva, Felipe. - Werther à luz da história do conceito de subjetividade

inovadora que, por fim, representa uma pré-história de nossa própria compreensão coletiva de 'sujeito' na Modernidade. ${ }^{7}$

Ao realizar essa manobra argumentativa, boa parte da crítica termina por justificar o esperado sucesso comercial da $\operatorname{obra}^{8}$ e, sobretudo, o tipo de fermentação literária por ela ocasionada nas gerações posteriores de escritores alemães. Os romances Ardinghello und die glückseligen Inseln (1787) de Wilhelm HeINSE, além de Anton Reiser (1785/94) de Karl Philipp MoRITZ, valem, por exemplo, como primeiras manifestações de obras continuadoras da temática wertheriana da 'tragédia do Eu', tragédia que encontrará repercussão no romantismo de Ludwig Tieck em diante. O que HAUSER (2000: 572) fala sobre o impacto de Rousseau na França poderia tranquilamente ser afirmado no que concerne ao impacto de Goethe na Alemanha:

[...] antes de Rousseau, exceto em certas formas de poesia lírica, um escritor só falava indiretamente a seu próprio respeito, mas, depois dele, os escritores dificilmente falavam de outra coisa, e da maneira mais livre e desembaraçada.

Esses são fatores objetivos da recepção do romance inicial de Goethe que, embora sejam relevantes para justificar sua inserção no cânone alemão, revelam-se como insuficientemente esclarecedores. E isso por uma razão central: eles não tocam, sequer superficialmente, em qualquer aspecto textual do romance em si para justificar o sucesso de sua acolhida em meio ao público da época - baseando-se, em vez disso, exclusivamente em dados extratextuais para tal. Neste sentido, falar que Werther é um romance sobre a subjetividade é como falar que Moby Dick é um bom livro sobre baleias; a formulação está longe de esclarecer o fenômeno.

Este artigo investigará o tipo de contribuição desse romance de Goethe para o discurso filosófico-cultural da subjetividade do século XVIII. Evitarei uma justificativa da obra como 'literariamente importante' assumindo que nela o jovem Goethe pretendeu traduzir os anseios e paradoxos de uma geração de leitores - já que nessa afirmação fica implícita a ideia errônea de que haveria alguma correspondência entre o

\footnotetext{
${ }^{7}$ LUKÁCS (1936 [1968]) expressa essa perspectiva em sua coleção de ensaios Goethe und seine Zeit: "The world success of Werther is a literary triumph of the bourgeois revolution. [...] Young Goethe artistically advanced the line of Richardson and Rousseau far beyond his predecessors. He took over their theme: the representation of the inner world of feeling in bourgeois daily life, in order to delineate in this inwardness the outlines of the emerging new man in opposition to feudal society."

8 Já que, depois de Fabeln und Erzählungen de Christian Fürchtegott Gellert (1746/8), Werther conta como o segundo grande bestseller alemão. Cf. BOYLE (1992: 175) e MATTENKLOTT (2004: 94).
} 
Vale da Silva, Felipe. - Werther à luz da história do conceito de subjetividade

conceito de subjetividade do jovem Goethe com ideais vigentes na cultura de sua época - e.g. da ainda incipiente cultura da classe burguesa alemã, e da cultura literária da Empfindsamkeit então em voga. Essa é uma suposição errônea, merecedora de maior detalhamento, e servirá como ponto de partida para a argumentação deste artigo.

Defenderei a perspectiva de que Goethe se destaca como um dos primeiros (e mais relevantes) críticos do individualismo como um valor em si - e do conceito moderno de sujeito autônomo - já em sua obra de 1774. O motivo de a obra obter êxito imediato em meio a seu público histórico - aquele público veiculador de certa tradição do individualismo - será analisado à luz do tipo de uso heterodoxo feito por Goethe do gênero literário consagrado na cultura da Empfindsamkeit, o romance epistolar. Ao mesmo tempo em que faz menção a instituições, autores e tendências comportamentais atrativas para seus contemporâneos - gerando uma identificação entre público e protagonista -, Goethe termina seu romance contra todas as expectativas do gênero sentimental, famoso por seus happy endings e conclusões moralizantes. O progressivo ensimesmamento e suicídio do protagonista ao final do livro serão analisados não como ato simbólico representativo da vitória de suas convicções (e autonomia) sobre um mundo caduco e inapto para atendê-lo (cf. LuKÁcs 1936 [1968]), mas como dados constitutivos de uma formulação crítica do estatuto da 'subjetividade moderna' por parte do jovem Goethe, assim como de sua avaliação das ideologias de sua época.

\section{A gênese da ideia de subjetividade moderna}

A partir do século XIX, tanto 'modernidade' quanto 'subjetividade' se reverteram em buzzwords exaustivamente empregadas (mas pouco esclarecidas) pela crítica literária (cf. BReITHAUPT 2002: 102). O maior problema de se falar em sujeito moderno, sobretudo no tom generalizante em que o termo é geralmente empregado, reside em assumir que o conceito é algo objetivo, e não uma forma cultural com historicidade própria (cf. FoUCAULT 1970: 308-309). A falta de consideração desse nível de análise leva boa parte da crítica a ignorar que não se encontrou uma definição positiva e una de sujeito moderno dentro do discurso filosófico, e certamente, em um nível de análise 
Vale da Silva, Felipe. - Werther à luz da história do conceito de subjetividade

literária, a questão não é essa. Nós nos ocuparemos com a identificação de aspectos ideológicos que guiaram as novas interpretações da condição humana em meados de 1770-1780. Foi somente então, ao menos na Alemanha, que se deu a gênese de um discurso exclusivamente voltado à problemática do sujeito, e que os termos das Ich e Ichheit passaram a ser usados dentro de uma terminologia coerente ${ }^{9}$.

A clara motivação por detrás desse discurso liga-se a um interesse crescente pela exploração da subjetividade em sua dimensão experiencial. Na nova imagem do sujeito do século XVIII, a pretensão da antiga metafísica de reduzir os sentidos do ser humano a uma essência fixa dá espaço ao escrutínio da individualidade do homem como um núcleo mais ou menos estável de significações, singular, aberto à análise e constante reinterpretação. A crescente predominância de uma investigação historicizada dos saberes sobre o homem permitiu à intelectualidade da época a constatação de que o conceito de sujeito - junto com valores acerca dos modos de vida, dos sentidos de sua existência - se reveste de significados diversos em contextos distintos.

A virada aqui mencionada realiza-se no ápice de um processo de alteração de referenciais epistêmicos da civilização ocidental (iniciado na Renascença, continuado pelo Iluminismo), que se expressa por um desmonte gradual da visão de mundo essencialista do período anterior. FIORIN (2008: 33) identifica no período a ocorrência de uma alteração de referências não apenas na antropologia, mas em todas as ciências. Essa alteração se caracteriza como uma inversão da "ordem das análises" científicas: se até o século XVIII as ciências buscavam reafirmar em seus argumentos a noção de habitarmos um "mundo matematicamente perfeito" que, por sua vez, só poderia "ressoar a perfeição divina", as ciências do século XVIII deixam de lado quaisquer pressupostos e passam a analisar seu tema de estudo como objetos autônomos, não mais subordinados a sistemas exteriores de valor - e.g. à teologia, aos poderes políticos, à tradição. As implicações para a 'questão do homem' se dão nesse nível: aqui apenas inicia-se um discurso da subjetividade interessado em compreender as novas funções e significados da existência individual humana no contexto moderno.

\footnotetext{
${ }^{9}$ O famoso periódico de Wieland, Der Teutsche Merkur, parece ter tido papel pioneiro na veiculação desse tipo de terminologia - e já em meados de 1780 são raros os periódicos que não façam uso dela. A respeito, ver BREITHAUPT (2002: 80-81).
} 
Vale da Silva, Felipe. - Werther à luz da história do conceito de subjetividade

Isso não implica, contudo, na negação de que há fatos fundamentais - de ordem psíquica, biológica, etc. - que determinam a experiência e a existência de cada ser humano em alguma medida; não obstante, a constatação desses dados simplesmente deixa de ser crucial para o novo acesso à questão. Pensar a subjetividade, aqui, envolve uma consideração de que os dados mais elementares da identidade pessoal não são fenomenologicamente vivenciados como dados brutos, mas se revestem de significações complexas - e muitas vezes instáveis, conflituosas - veiculadas no corpo social do qual o indivíduo inicialmente retira seus significados, linguagem e gestos sociais. Esse indivíduo, ao invés de meramente atuar sobre dados biológicos ou divinamente designados que constituiriam uma identidade pronta e imutável do Eu, constitui-se como algo apenas na medida em que é interpretado / se interpreta como portador de certa identidade.

A repercussão popular deste novo modelo de análise pode ser identificada em forma embrionária em certos grupos religiosos (como o dos pietistas) e modas comportamentais (Empfindsamkeit) ${ }^{10}$ do século XVIII. Ambas as culturas mostram-se inclinadas a explorar a vida anímica do homem moderno, investigar a trajetória de amadurecimento supostamente prevista para cada indivíduo em sua missão de conquista de um espaço no mundo. Para elas, a Modernidade não é recebida como processo civilizatório progressivo, e seus dois pilares - a visão de mundo racionalista e a sociedade burguesa - são ressaltados como incapazes de fornecer sentidos palpáveis para as necessidades existenciais mais básicas do ser humano. Esses dois códigos culturais, assim, ganham popularidade no imaginário do período justamente por problematizar a nova sociedade em formação na época, apelando para uma volta a valores tradicionais. Ou seja: já haveria aqui uma formulação inicial do processo histórico de modernização como causa da cisão entre indivíduo e uma comunidade/ordem simbólica que anteriormente o representou, e sobre a qual os valores ocidentais se construíram. É um fenômeno central dessa transição o fato de a subjetividade, no contexto pontuado, virar um problema de cunho axiológico quando o indivíduo se vê destituído de uma complexa gama de valores que, em sociedades estratificadas, mediara o contato do homem com a ordem simbólica social. Um dado essencial da experiência dos sujeitos de então é o sentimento de cisão com uma

\footnotetext{
${ }^{10}$ Mencionada, a partir de agora, como 'Sentimentalismo' (em letra maiúscula).
} 
Vale da Silva, Felipe. - Werther à luz da história do conceito de subjetividade

totalidade harmônica, com o mundo, a sociedade e a esfera do Divino, de forma que ele se vê simultaneamente livre e (ainda em maior medida) impelido a determinar seu caminho no mundo por seus próprios esforços. Por esse motivo, no novo direcionamento intelectual visto em tais códigos culturais, observa-se um curioso apelo à valorização do amor fraternal e ao cultivo da dimensão emotiva do ser humano, com um fim expresso de 'anular' os efeitos negativos da modernização europeia sobre a vida comum (cf. SLOTERDIJK 1993: 53 e 60).

Nesse estado de discussão, encontramos o texto literário como órgão privilegiado de análise da nova subjetividade. Uma vez que, como mencionado, as manifestações culturais sobre a subjetividade abandonam pretensões de deduzir uma essência humana, observa-se o crescente interesse do público literário do período por amostras da experimentação do homem consigo mesmo, pela vivência passo-a-passo da vida íntima do sujeito, pela exploração da complexidade psicológica desse novo modelo de indivíduo moderno definidor de seu próprio destino - e nesse quesito a crescente veiculação de romances em meio à esfera pública a partir do século XVIII parece uma comprovação desta mudança de orientação intelectual (cf. MCKEON 2000: 382). No tópico que se segue isolaremos o caso do Sentimentalismo como a cultura literária mais significativa para a presente pesquisa, por ser aquela com a qual Goethe dialogaria diretamente em seu romance inicial.

\section{$3 \bigcirc$ Sentimentalismo como novo paradigma literário}

Em meados de 1745, o Sentimentalismo (Empfindsamkeit ou Zärtlichkeit) surge na Alemanha como tendência moral, psicológica e literária. Não se configurando propriamente como 'escola literária', sua influência na produção literária da época é percebida na medida em que fomenta certas discussões acerca da sensibilidade humana - de sua importância moral e papel constitutivo da identidade do sujeito (SAUDER 2004: 248). Até essa tendência entrar na cena cultural alemã, a discussão sobre a questão subordinou-se à autoridade intelectual racionalista da qual estavam investidos Christian Wolff e seus pupilos (cf. KUEHN 1996: passim). Para esses Aufklärer, a dimensão da emotividade se subordinaria a uma estrutura moral supostamente natural ao gênero 
Vale da Silva, Felipe. - Werther à luz da história do conceito de subjetividade

humano; os parâmetros morais possuiriam, assim, o status de universais, sendo dedutíveis por meio do exercício adequado da razão. Segundo essa teoria da agência moral, era tarefa do sujeito fazer uso de seu entendimento para concluir, sozinho, a inquestionabilidade daquilo que é correto ou não. As emoções estariam abaixo do uso matemático da razão: sentimentos não são válidos por si só, de forma que o indivíduo autônomo é aquele capaz de controlar-se e direcionar suas motivações mais íntimas a fins exclusivamente práticos.

A concepção da emotividade humana proposta pelo Sentimentalismo vai diretamente contra o tom demasiadamente generalizador dessas teorias, avesso à efetividade da vida do sentimento e sua complexidade como fenômeno mediador da experiência humana. A necessidade de uma perspectiva filosófica mais fiel à multivariedade da vida sentimental, assim como seu papel no todo da existência humana, acaba por encontrar na teoria de autores escoceses e ingleses (Shaftesbury, Hume e Hutcheson) uma base teórica mais adequada. $\mathrm{O}$ uso das ideias dos filósofos britânicos pela Empfindsamkeit não possui grande rigor filosófico; o Sentimentalismo visa muito mais servir ao desmonte dessa espécie de racionalismo vigente no discurso acadêmico da época (KUEHN 1996: 262) e, nesse sentido, possui influência relevante no comportamento social de sua geração. Essa busca por redefinição da compreensão filosófica da sentimentalidade teve como alvo, historicamente, o desenvolvimento de novas formas de sociabilidade. Essa teoria funda-se sobre a crença de que há um sentimento de fraternidade inerente a cada ser humano, mas que só se torna efetivo se desenvolvido propriamente.

O Sentimentalismo deixa marcas no comportamento de toda uma geração de escritores que produziram suas obras literárias entre as décadas de 1740 a 1770 . A difusão da tendência se dá em meio a um público leitor que, guiado por uma busca de conteúdos emocionais em sua experiência de mundo, renova a recepção da arte e se deixa renovar por ela. Vale como uma peculiaridade da cultura de leitura do século XVIII a ênfase na capacidade de que o texto literário bem estruturado deveria suscitar determinados estados anímicos em seu leitor, de forma a confrontá-lo com situações imaginárias que, por fim, lhe permitiriam se conhecer melhor e se relacionar de forma produtiva com suas inclinações não-racionais. Daí a ideia do uso da literatura com a finalidade de promover uma espécie de educação das afecções íntimas. 
Vale da Silva, Felipe. - Werther à luz da história do conceito de subjetividade

Desenvolve-se, assim, uma linguagem voltada a expressar a consciência que as personagens têm de si, por meio de aparatos técnicos que terminam por influir na escrita de cartas pessoais e autobiografias de toda uma geração; tal linguagem sentimental serviu a estes indivíduos como manifestação de sua autoexpressão perante seus iguais, na construção de sua face social, permitindo a eles lançarem-se conscientemente sobre um modo de vida que lhes parecia 'autêntico' - como que se brotasse do íntimo. A ideia de 'autenticidade', em si vaga, como ainda hoje o é, despertava o interesse daqueles que observavam as mudanças comportamentais da sociedade do século XVIII, na medida em que legitimava mudanças comportamentais de indivíduos sensibilizados pelo ideario iluminista. Passa a vigorar a noção de que o indivíduo autônomo e 'auto realizado' é um indivíduo mais apto para a vida na sociedade sonhada pelos iluministas. É nesse sentido que encontramos um significado maior do Sentimentalismo na história cultural alemã, como uma manifestação cultural da Aufklärung em si, que se empenhou em repensar o uso da literatura e das artes em geral com fins ideológicos bastante específicos.

Na literatura do Sentimentalismo, a obra se converte em síntese expressiva de uma situação afetiva explorada em seu imediatismo, em seu estado espontâneo. Nesse contexto, a figura do leitor ganha um peso nunca antes visto na gênese mesma de obras artísticas. Aspectos formais que promovem o vínculo entre leitor e texto passam a ser vastamente utilizados. Nessa chave, o princípio racional de leitura (i. e., cronológica, concatenada, que encara o texto de ficção como uma sucessão de eventos que constitui um todo estético e conceitual, a ser julgado racionalmente) dá lugar a uma leitura de identificação, como veremos no caso de Richardson.

O produto literário que se mostrou mais significativo dessa tendência foi, sem dúvida, o romance epistolar. Esse tipo de forma literária do Sentimentalismo inaugurada pelo romancista inglês Samuel Richardson em seu Pamela or virtue rewarded (1740) ${ }^{11}$ - atende à dinâmica desse ambiente cultural como poucos modelos romanescos anteriores. O fator diferenciador do tipo de romance de Richardson é a transposição para a ficção do imediatismo do discurso entre indivíduos que trocam correspondências; seus textos são supostas coletâneas de cartas entre conhecidos. Tal

\footnotetext{
${ }^{11}$ A primeira tentativa alemã no gênero se dá com a obra de C. F. Gellert Leben der schwedischen Gräfin von $G^{* * *}$ (primeira publicação em 1747/48). O estudo de Eva BECKER (1964: 167) traz o surpreendente dado de que, em meados de 1780, um terço dos romances lançados na Alemanha era epistolar.
} 
Vale da Silva, Felipe. - Werther à luz da história do conceito de subjetividade

artifício servirá à aplicação de um princípio de dissolução da distância épica na comunicação de processos anímicos das personagens de ficção, de encurtamento da artificialidade e da distância narrativa própria do texto em prosa. O narrador épico é aqui substituído por um editor supostamente imparcial, que organiza o material exposto - um material que parece falar por si mesmo. É assim que seus romances epistolares, por 'excluírem' a mediação direta de um narrador onisciente, incumbem o leitor de deduzir e formar o todo da identidade das personagens a partir de seus discursos e das reações emotivas espontâneas às situações da trama. O leitor, para efeitos práticos da fruição desta categoria romanesca, assume o papel de confidente do protagonista no modelo proposto. O que ele sabe sobre as personagens da trama advém de um exercício de dedução de suas personalidades, é fruto direto do julgamento moral daquele que lê e se envolve emotivamente no melodrama.

Um segundo dado sobre esse tipo de romance refere-se ao encadeamento dos fatos narrados: eles se configuram como uma sequência que permite vislumbrar o desenvolvimento de várias perspectivas sobre a sentimentalidade da personagem, sem se aterem meramente a montagem de um fio de ação que culmina em um clímax, como no modelo épico mais tradicional (cf. HAUSER 2000: 517). Estabelece-se a partir daí um contrato ficcional de natureza diversa do contrato da narrativa épica mais objetiva. $\mathrm{O}$ grau de verossimilhança passa a ser buscado não na trama em si, que é geralmente bastante corriqueira; é no desenlace psicológico das personagens, na profundidade de sua relação com as situações, que residirá o cerne do texto. A verdade psicológica mediada pelas complicações que deles derivam se torna mais importante que os eventos. Nesta 'verdade psicológica', por fim, residiria o elemento reflexivo - e moralmente edificante - da modalidade literária intentada pelos autores pioneiros do gênero (cf. BECKER 1964: 6; SAUDER 2004: 248).

Isso confere, contudo, certa rigidez a esses romances - pouco atrativa para o leitor atual -, além de certa previsibilidade do desfecho de suas tramas. O happy ending é elemento obrigatório nesse tipo de registro literário já em Richardson, pois o objetivo declarado do autor ao escrever sua obra é o de veicular os opúsculos morais que as fecham, comprovando assim a vitória inquestionável da virtude sobre o vício, do bem sobre o mal. O interesse do autor com este tipo de literatura era o de derivar de suas tramas uma série de ensinamentos morais. Dessa forma ele "assume o papel de um 
Vale da Silva, Felipe. - Werther à luz da história do conceito de subjetividade

conselheiro espiritual, [que] discute os grandes problemas da vida, força o leitor a examinar-se, esclarece-lhe as dúvidas e ajuda-o com juízos paternais" (HAUSER 2000: 564). A recepção real dessas obras, contudo, acaba por frustrar essa intenção. Gera-se um efeito contrário ao da moralização; um culto expresso a vilões das histórias ou, por outro lado, uma celebração do sentimentalismo por si só. $\mathrm{O}$ sucesso desse empreendimento de moralização, portanto, é discutível, e acaba por servir como fenômeno de recepção e indício do tipo de elemento buscado pelos leitores: não propriamente um guia moral, mas mera ocasião para dar vazão a seus sentimentos.

Essa dinâmica de fruição do texto literário torna-se uma verdadeira moda quando passa a ultrapassar as barreiras da literariedade e a incidir sobre a escrita de cartas pessoais de toda uma geração (cf. DUNCAN 1999: 50-53). Observa-se uma curiosa relação circular do gosto literário e das convenções epistolares de então: por um lado o público que escreve cartas se inspira nos romances que lê, ao passo que os escritores de romances se utilizam vastamente do linguajar de cartas 'sentimentais' enviadas por pessoas reais. ${ }^{12}$ Os princípios de escrita epistolar chegarão a sofrer uma tentativa de formalização por parte do escritor Christian Fürchtegott GELLERT, em um compêndio de regras práticas "do bom gosto em cartas" (Briefe, nebst einer Praktischen Abhandlung von dem guten Geschmacke in Briefen, de 1751 [1989]). Tal compêndio entrou imediatamente em voga nos círculos literários alemães, deixando profundas marcas no Werther de Goethe. Gellert postula o bom gosto para cartas de acordo com princípios de naturalidade da fala e da livre expressão dos sentimentos, contra o que ele chama de Kanzleistil - o estilo de escrita oficial, neutro e repleto de formalidades. A comunicação íntima proposta pelo autor (id.: 111; 126) encontra sua identidade no traço individual diferenciador, no cultivo do sentimento e sua veiculação livre de informalidades tidas como desnecessárias. O pano de fundo desta proposta traz uma visão antropológica que preza a simplicidade e espontaneidade do indivíduo para com seus iguais. Para ilustrar a radicalidade com que estas experimentações sociais foram vividas na Europa da época, Jürgen HABERMAS (2003: 67) nos conta a curiosa anedota a respeito do círculo de amizades de Madame de Stäel - autora de D'Allemagne - em cuja casa se "cultiva desenfreada vida social e na qual, após a refeição, todos os convivas se retiram para

\footnotetext{
${ }^{12}$ Lembremos que no século XVIII era bastante comum que as cartas de pessoas célebres (sobretudo) fossem publicadas.
} 
Vale da Silva, Felipe. - Werther à luz da história do conceito de subjetividade

escrever cartas uns aos outros"; é aqui que o autor tem prova do teor fantasioso do sentimento de amizade propagado no Sentimentalismo: "torna-se evidente que as pessoas se tornavam, para si e para os outros, sujets de fiction."

Podemos partir desses dados para pontuar que há sim verossimilhança na excessiva sensibilidade com que o jovem Werther se abre com seu correspondente Wilhelm no romance de Goethe, assim como na forma como se relaciona com Lotte. ${ }^{13}$ A distância histórica e alterações comportamentais que separam o século XVIII alemão do século XXI levam-nos a negligenciar o quanto o tipo de sensibilidade do protagonista do romance aproxima-se de um tipo psicossocial próprio dessa época de virada que foi a década de 1770. Tal sensibilidade foi vista como 'progressiva' (em um sentido iluminista do termo) para algumas gerações de jovens europeus, funcionando quase como manifestação de uma revolução comportamental promotora de um comunitarismo ideal, ainda inexistente na sociedade de então. Nessa chave de leitura, pode-se afirmar que o Sentimentalismo simula os valores de mobilidade universal e diluição de relações sociais coercitivas, como foram veiculados em certo discurso iluminista, ainda que apenas em um plano microcósmico - e.g., em círculos de pessoas afins, intelectualizadas, e quase sempre de mesma posição social. O sucesso ou efetividade desse tipo de resistência coletiva à caduca ordem social do fim do feudalismo, contudo, parece já bastante questionável para o Goethe do Sturm und Drang. O tipo de caminho que ele, como narrador, trilha para seu 'homem sentimental' exemplar, o jovem Werther, será foco de nossas atenções para que possamos derivar um posicionamento do autor perante a questão do sujeito.

O diferencial mais evidente de Werther é o profundo trabalho de seu autor nos aspectos da incongruência da 'alma sensível' com o ambiente em que ela se insere, o tipo ambiente social árido do Sacro Império, regido por instituições extremamente retrógradas e inférteis para o modelo de sociedade harmônico que o otimismo dos Aufklärer e Sentimentalistas poderia almejar. O conhecido desfecho que o Goethe-autor reserva a seu próprio personagem Sentimental revela, assim, muito de seu posicionamento crítico ao otimismo da cultura literária da época. Em vista do final de Werther, somos confrontados com a perspectiva de que o espaço do sujeito no mundo

\footnotetext{
${ }^{13}$ Cf. Swales \& Swales (2002: 71); Swales (2002: 6-7); MuenZer (1984: 148-9, nota 2).
} 
Vale da Silva, Felipe. - Werther à luz da história do conceito de subjetividade

não está garantido - seja por meio de instituições, na natureza ou no seio da comunidade. O ideário do Sentimentalismo resulta em mero ideário, negado de antemão pela efetividade do funcionamento social, infinitamente mais tortuoso para certos indivíduos movidos pela busca de desenvolvimento de suas personas no seio de uma comunidade. Nessa chave podemos ler o retrato goethiano do Sentimentalismo (e de sua insuficiência).

\section{A presença do discurso sentimental em Werther}

Lerei Werther como um produto cultural cuja gênese se dá em meio à cultura do Sentimentalismo, sendo assim portador de nuances que podem ser compreendidas de forma mais elucidativa na medida em que as contrapomos a valores ideológicos e estéticos desse ambiente cultural. Quando Werther foi lançado, não havia por parte do público literário alemão uma distinção propriamente articulada entre uma literatura Sentimental e uma literatura do Sturm und Drang (cf. Duncan 1999: 26-27). O romance inaugural de Goethe, ao contrário, elegantemente constrói uma figura que se mostrou, em face de sua própria história de recepção, singularmente atrativa e intrigante para o mesmo público que consumia Richardson ou Gellert. Os leitores iniciais da tragédia do jovem Werther não só admiraram sua história, mas identificaram com espanto suas próprias inquietudes e contradições espelhadas em seus monólogos (cf. Matos 2008: passim). Werther torna-se imediatamente uma moda literária justamente por ser um romance sobre uma moda e por articular impasses existenciais de sua época de forma inovadora, ao mesmo tempo em que polemiza com valores morais/religiosos bem calcados e atesta a revolta perante modos de vida tradicionais.

Mencionou-se anteriormente que, se Goethe se utiliza do modelo do romance epistolar sentimental, ele o faz de forma heterodoxa. Goethe vale-se de uma dupla estratégia na narrativa dos sofrimentos de Werther. Em primeiro lugar, o autor vale-se da convenção literária do romance epistolar e se utiliza de elementos 'esperados' e atrativos para seu leitor contemporâneo; ao fazê-lo, ele remete a todo um horizonte de expectativas literárias bastante específicas. No imaginário popular do Sentimentalismo, 
Vale da Silva, Felipe. - Werther à luz da história do conceito de subjetividade

uma trama romanesca - apesar de se construir ao redor de complicações intersubjetivas e crises emotivas - atinge seu objetivo 'educacional' ou 'edificante' justamente com o final feliz. Esse desfecho atesta a vitória da virtude sobre as vicissitudes da vida comum. Ele é o momento de confirmação 'de fato' (no qual a visão de mundo da Aufklärung apostou) de que a integração social efetiva entre pessoas afins é o estado reservado a homens e mulheres que perseveram nos ideais de Geselligkeit e buscam uma forma de convivência natural e transparente. Esse momento de fechamento harmônico é justamente o que não existe em Werther - e aqui identifico o segundo aspecto da 'estratégia' de seu autor. A própria recusa de dar um final feliz à história de Werther, assim como a ausência de qualquer conclusão moralizante possível para sua tragédia, põe em xeque o otimismo contido na visão de mundo segundo a moda sentimental.

A frustação desta expectativa funciona de forma calculada no romance: Goethe situa essa decepção no momento final de um romance que, em seu início, recorre a toda sorte de apelos para a identificação entre leitor e protagonista, provinda da "geração de confidência”, tão peculiar à dinâmica de leitura dos romances epistolares tradicionais. Goethe até mesmo intensifica a estratégia de identificação ao se valer de um mecanismo narrativo até então inédito na literatura: diferentemente do romance epistolar tradicional, construído a partir da troca de cartas entre várias pessoas, em Werther temos uma narrativa quase exclusivamente monológica. É certo que o protagonista se dirige em suas cartas a certo Wilhelm - contudo, nada no romance nos conta a respeito desta segunda figura, de forma que ela não se constitui de fato como personagem, no sentido de carregar características identificadoras ou participar da experiência da trama em qualquer nível. No texto, será o leitor quem reagirá às flutuações emotivas do protagonista conforme os eventos se desdobram no texto; as cartas de Werther, como elucidado por BoYle (1992: 170), seriam de fato, no nível de fruição, dirigidas a esse leitor, que assume papel de confidente no texto.

O vínculo de comunicação entre autor e um leitor supostamente predisposto a encontrar identificação com a obra é proposto logo em seu prefácio e em termos bastante específicos. O livreto é dedicado àqueles cuja condição pode ser representada pela história dos sofrimentos de Werther. Na página de abertura, lê-se: 
Vale da Silva, Felipe. - Werther à luz da história do conceito de subjetividade

Was ich von der Geschichte des armen Werther nur habe auffinden können, habe ich mit Fleiß gesammelt und leg es euch hier vor, und weis, daß ihr mir's danken werdet. [...] Und du gute Seele, die du eben den Drang fühlst wie er, schöpfe Trost aus seinem Leiden, und laß das Büchlein deinen Freund seyn, wenn du aus Geschick oder eigener Schuld keinen nähern finden kannst. ${ }^{14}$ (Werther: 10; carta de 04 de maio de 1771)

Há uma enorme economia de detalhes nessa breve, mas rica exposição: o livro como um todo - e não a figura de Werther - é recomendado para ser aceito como "companheiro" pelo leitor. Concomitantemente, o conselho carrega uma estranha sugestão de que o leitor substitua o contato humano pela identificação com o livro; somos simultaneamente confrontados com a perspectiva de nos identificarmos com o "pobre Werther" e nos distanciarmos de seu destino no momento propício, seja lá qual for.

Esse é um detalhe extremamente sutil do prefácio, mas crucial para identificarmos o tipo de operação aqui intencionada - até então, permanece ambíguo o tipo de relação 'texto-leitor' proposta para a narrativa. A sugestão propõe uma síntese de distanciamento e aproximação para com a história a ser apresentada. Este tipo de relação dupla de identificação / distanciamento seria uma espécie de relação que remete à reflexão poetológica contida no romance, cujas implicações serão válidas para nosso balanço do posicionamento crítico de Goethe perante o Sentimentalismo.

Uma vez identificadas certas peculiaridades do prefácio do romance, traçarei a seguir uma análise detida de seus episódios.

\section{A busca por totalidade: Werther como sensualista}

Wie froh bin ich, daß ich weg bin! Bester Freund, was ist das Herz des Menschen! Dich zu verlassen, den ich so liebe, von dem ich unzertrennlich war, und froh zu seyn! Ich weis, Du verzeihst mir's. ${ }^{15}$ (Werther: 10; 04 de maio de 1771)

\footnotetext{
14 "Tudo aquilo que me foi dado encontrar na história do pobre Werther, eu ajuntei com diligência e agora deposito à vossa frente, sabendo que havereis de me agradecer por isso. [...] tu, boa alma, que sentes o Ímpeto da mesma forma que ele o sentiu, busca consolo em seu sofrimento e deixa que o livreto seja teu amigo se, por fado ou culpa própria, não podes achar outro mais próximo do que ele." (tradução em GOETHE 2001: 11).

15 "Como estou contente de ter partido! Ah, meu amigo, o que é o coração humano! Deixar-te, a ti que eu tanto amo, de quem eu era inseparável, e estar contente! Sei que me perdoarás.” GoETHE (2001: 12).
} 
Vale da Silva, Felipe. - Werther à luz da história do conceito de subjetividade

No trecho de abertura da trama, lemos o relato do protagonista acerca da necessidade que o levou a fugir de sua terra natal e a buscar uma nova vida. Werther contempla com certo entusiasmo o futuro incerto que tem a sua frente, em local e circunstâncias capazes de lhe prover um tipo de bem-estar que não encontrava mais em sua vida antiga. Ao mesmo tempo em que comunica seu contentamento, Werther não esconde certo pesar que sente ao imaginar-se longe de seu correspondente Wilhelm.

Inicia-se neste breve relato a contraposição entre dois sentimentos que se tornará central no decorrer da história: Werther divide-se entre sua afeição autêntica por seus entes queridos e a impossibilidade de manter uma convivência real com eles, impossibilidade supostamente desencadeada por causas exteriores (neste caso, como vemos no trecho imediatamente posterior, a causa seria uma complicação amorosa pouco explicada com uma "Leonore" e sua irmã). O que fica evidente até esse momento da narrativa é a certa inclinação do protagonista por escolhas pautadas em decisões radicais. Do seu ponto de vista é plenamente aceitável fugir de um caso amoroso problemático se isso puder livrá-lo do fardo de ter de remoer seu passado a todo instante, impedindo-o de gozar a vida.

Werther expõe sua perspectiva no sentido de que o ser humano só pode encontrar a verdadeira paz existencial quando domina sua tendência natural de se ocupar com especulações infrutíferas acerca do passado. O presente imediato é verdadeiro terreno do homem ativo, capaz de gozar sua vida plenamente. É bastante claro que a missão atual de Werther está ligada a um desejo de conquistar seu próprio lugar neste presente, embora ele não tenha certeza de como isso poderá ocorrer. Seu pressuposto para tal é o de que é necessário isolar-se e evitar contato com qualquer companhia ou estímulo sensorial que lhe traga o passado à tona. A opção pela nova postura existencial - implícita em sua fuga - rende bons resultados imediatos. A complicação amorosa passada escapa de suas preocupações já na próxima carta, datada de 10 de maio. Não só Leonore deixa de ser citada, como Werther dirige sua atenção para o aperfeiçoamento de sua técnica de pintura, uma forma artisticamente satisfatória para expressar sua experiência de vida. ${ }^{16}$

\footnotetext{
${ }^{16} \mathrm{O}$ leitor toma consciência de que Werther é um pintor amador quase casualmente, mas ressalto a importância deste detalhe. O pintor amador é aquele indivíduo em busca do aperfeiçoamento de sua técnica expressiva, de um registro pessoal que faça jus à sua imagem íntima de mundo, à perspectiva que
} 
Vale da Silva, Felipe. - Werther à luz da história do conceito de subjetividade

É válido ressaltar alguns aspectos da repercussão desse primeiro panorama em meio ao texto. A busca por uma "experiência imediata", somada à procura do desenvolvimento de uma percepção adequada para sua produção artística, caminham como duplo objetivo da trajetória do jovem, constituindo-se no tema que une a primeira à última carta da obra. Ainda que desde o início do romance Werther se declare acometido por uma estranha incapacidade de pintar ou reagir produtivamente aos estímulos estéticos que o circundam, ${ }^{17}$ isso não invalida sua intenção de reproduzir esteticamente suas impressões do mundo exterior. Há um registro dessa inclinação na própria opção por um tom poético para suas cartas. Elas não são apenas a expressão de dados objetivos de sua vida para Wilhelm, mas já são produto de um acesso estetizante à experiência de vida, tingido de convenções da lírica pastoral e Sentimental da época (cf. SWALES 2002: 133). Werther está a todo o momento valendo-se de um universo discursivo poético, buscando um código adequado para dar conta daquilo que "so warm in [ihm] lebt" (carta de 10 de maio). Na medida em que ele abandona a pintura e se restringe a se expressar por meio de suas cartas, nota-se uma alternância do veículo expressivo, mas não a essência da busca.

Interpreto o motivo do aperfeiçoamento da expressividade como signo de uma motivação existencial do protagonista em articular, no âmbito de sua fantasia poética, um sentido palpável para sua experiência vital. Ao escolher o meio artístico para fazêlo, Werther revela suas pretensões de extrair sentidos superiores da existência, que se sobreporiam à aridez da vida ordinária que os homens estão destinados a viver. ${ }^{18}$

A vivência do gênio carrega nesse romance um paradoxo fundamental capaz de fornecer-nos um acesso ao que Werther tem como 'falta existencial' motivadora de sua busca por expressividade. Em vista do rico emaranhado de circunstâncias e problemáticas abertas nas duas primeiras cartas do romance, partimos da imagem de um Werther portador de uma missão - ao menos em um primeiro momento - própria de um sensualista, não de um individualista. De fato, é difícil imaginarmos esse primeiro

ele, como Genie, tem a oferecer para o mundo. O amadorismo de Werther, por si só, é sugestivo de que ele ainda não encontrou esse registro. Cf. Werther: 14; 10 de maio.

${ }^{17}$ Id. Analisaremos a passagem em questão no ponto seguinte.

${ }^{18} \mathrm{O}$ posicionamento contra a vida ordinária à qual os homens estariam destinados a viver é explícita na carta de 17 de maio (Werther: 18-20): "Se me perguntares como são as pessoas por aqui tenho de te responder: como em todo lugar! É uma coisa bastante uniforme a espécie humana. Boa parte dela passa seus dias trabalhando para viver, e o poucochinho de tempo livre que lhe resta pesa-lhe tanto que busca todos os meios possíveis para livrar-se dele. Oh, destino dos homens!“(GoETHE, 2001: 18-19). 
Vale da Silva, Felipe. - Werther à luz da história do conceito de subjetividade

momento do livro sem o contato efetivo com o mundo exterior; ele necessita da exterioridade, seu entusiasmo está diretamente ligado à descoberta do mundo. Werther ainda não narra sua vida interior diretamente e dificilmente gozaria das sensações que expressa sem este contato com as belas paisagens que o circundam; o mundo exterior serve, assim, como intermediador da relação de sua subjetividade com sua própria sentimentalidade (cf. MUENZER 1984: 8). Caracteristicamente, porém, o sensualismo de Werther está permeado por um pressuposto ilusório de que o mundo exterior se colocaria à sua plena disposição, ou ao menos à disposição de indivíduos que, como ele, possuem o tipo de sensibilidade que ele estaria inclinado a cultivar e expressar para seu confidente. ${ }^{19}$

\section{$6 \bigcirc$ Genie silenciado: o paradoxo do artista}

O fracasso da missão inicial não demora a se mostrar evidente. Há um paradoxo inerente à sua exaltação da natureza: ao mesmo tempo em que o mundo natural preenche sua fantasia artística provisoriamente, o protagonista não consegue fazer nada palpável com o rico material sensorial que tem em mãos. Ele assume que a natureza é demasiadamente sublime para sua compreensão, o bastante para anestesiar suas faculdades expressivas. Em seu atual estado de espírito, Werther admite que o ato de expressar algo artisticamente (no caso, via pintura) resultaria em um ato oco: na criação de cópia infiel da riqueza de impressões que o acometem nesse idílio. E ele complementa, paradoxalmente: "Ich könnte jetzt nicht zeichnen, nicht einen Strich, und bin nie ein größerer Maler gewesen als in diesen Augenblicken",20.

Nas palavras de MUENZER (1984: 13s), em um primeiro momento tal verbalismo sofístico da linha de pensamento do protagonista parece apontar mais para sua tendência ao autoengano do que para uma resolução autêntica para seu fracasso. ${ }^{21}$ Entretanto, é

\footnotetext{
19 "Estou tão só e minha vida é feita de alegrias por viver numa região que parece ter sido criada para almas como a minha" (Werther: 14, carta de 10 de maio. Tradução em GOETHE (2001: 14).

${ }^{20}$ Ibid., idem. "Não posso desenhar, nem uma linha, e ainda nunca fui um pintor tão grande como sou neste momento" (tradução minha).

${ }^{21}$ E.g. para seu fracasso como pintor e para o fracasso de sua busca pessoal -que ficará claro no final do romance, quando Werther se suicida, mas que já podemos 'identificar 'se insinuando' aqui.
} 
Vale da Silva, Felipe. - Werther à luz da história do conceito de subjetividade

digno de nota observarmos, no trecho que se segue, que Werther empreende uma descrição da paisagem que vivencia carregada, justamente, do teor artístico (e.g. poético) que lhe faltara em sua pintura:

\begin{abstract}
Wenn das liebe Tal um mich dampft, und die hohe Sonne an der Oberfläche der undurchdringlichen Finsterniß meines Waldes ruht, und nur einzelne Strahlen sich in das innere Heiligtum stehlen, und ich dann im hohen Grase am fallenden Bache liege, und näher an der Erde tausend mannigfaltige Gräsgen mir merkwürdig werden. Wenn ich das Wimmeln der kleinen Welt zwischen Halmen, die unzähligen, unergründlichen Gestalten der Würmgen, der Mückgen näher an meinem Herzen fühle, und fühle die Gegenwart des Allmächtigen, der uns nach seinem Bilde schuf, das Wehen des Alliebenden, der uns in ewiger Wonne schwebend trägt und erhält. Mein Freund! wenn's dann um meine Augen dämmert, [...] dann sehne ich mich oft und denke: ach könntest du das wieder ausdrücken, könntest du dem Papiere das einhauchen, was so voll, so warm in dir lebt, daß es würde der Spiegel deiner Seele, wie deine Seele ist der Spiegel des unendlichen Gottes! $!^{22}$ (Werther: 14; 10 de maio)
\end{abstract}

O que ocupa a busca do artista não é o interesse pela dimensão técnica da arte. Muito pelo contrário, sua contemplação da paisagem se expressa em termos de uma união mística com a natureza. ${ }^{23} \mathrm{O}$ esplendor unifica cada elemento desse complexo quadro natural, de forma que, para o Werther-pintor, a mimetização desse momento se torna impossível. Werther insiste em ressaltar que o extremo valor que a epifania teve para ele - e, consequentemente, o 'passo a frente' que isso representa para sua autoimposta busca sensualista - reside no caráter irreprodutível da vivência, no suposto vivenciar de uma unidade entre sujeito e totalidade, na dissolução do principium individuationis que vale aqui como a verdadeira fonte da angústia do homem no mundo. Essa é a

\footnotetext{
22 "Quando a bruma do vale se levanta à minha volta, e o sol altaneiro descansa sobre a abóbada escura e impenetrável da minha floresta, e apenas alguns escassos raios deslizam até o fundo do santuário, ao passo em que eu, deitado entre a relva alta, na encosta de um riacho, descubro no chão mil plantinhas desconhecidas... Quando sinto mais perto de meu coração a existência desse minúsculo mundo que formiga por entre a relva, essa incontável multidão de ínfimos vermes e insetinhos de todas as formas e imagino a presença do Todo-Poderoso, que nos criou à sua imagem e semelhança, e o hálito do TodoAmado que nos leva consigo e nos ampara a pairar em eternas delícias... Ah, meu amigo, quando o mundo infinito começa a despontar assim ante meus olhos [...], então suspiro profundamente e penso: Ah! Pudesses tu voltar a expressá-lo, pudesses tu exalar o sentimento e fixar no papel aquilo que vive em ti com tanta abundância e tanto calor, de maneira que o mesmo papel pudesse se fazer o espelho de tua alma, como tua alma é o espelho do Deus infinito!" (cf. GOETHE, 2001: 14-15).

${ }^{23}$ É interessante atentar para o fato de que a articulação da experiência de suposta união com a natureza está entremeada por cultura: a construção frasal da citação, caracterizada pela concatenação de condicional "wenn... wenn... dann...", é exemplar do discurso do Sentimentalismo; a exaltação religiosa, ainda que apresente certas nuances panteístas, retoma estratégias retóricas de tradição homilética. Cf. SWALES (2002: 133) para uma análise do discurso do trecho.
} 
Vale da Silva, Felipe. - Werther à luz da história do conceito de subjetividade

constatação que fica implícita dentro da metafísica tipicamente wertheriana. A visão do Todo em cada elemento singular que o compõe, contudo, não se sustenta por muito tempo. Eis que se vê uma quebra com o relato da epifania, quando o autor da carta complementa: "Aber ich gehe darüber zu Grunde, ich erliege unter der Gewalt der Herrlichkeit dieser Erscheinungen"24.

É interessante notar como, por força do próprio registro monológico empregado por Goethe no romance, nos falta uma opinião efetivamente objetiva que comente e relativize as ilusões de Werther. A evidência de seus fracassos, contudo, não permanece oculta aos leitores do romance que julgam o texto literário de modo objetivo; isto é, pode-se constatar, no decorrer da história, a acumulação de evidências do fracasso do sujeito que aspira em conflito com a realidade. O caráter monólogico do texto permite ao leitor deduzir posturas existenciais e crenças metafísicas do protagonista - como apontado acima, a espécie de schopenhaurianismo avant la lettre contida em sua visão de mundo - e criticá-las como insuficientes, tanto em um nível prático quanto conceitual. Um dado central evidencia que Goethe não se aliaria, de forma alguma, à visão de mundo de Werther (e a todo aparato cultural/conceitual ao qual ela remete). Esse dado é: nos momentos em que o personagem se mostra convencido de ter aprendido algo novo, de forma a avançar em sua missão pessoal de autodescoberta, algum fator externo acaba por frustrar suas expectativas. Ao trazê-lo de volta para a realidade opaca da qual ele só quer distância, essa fatualidade do mundo dá corda ao mecanismo de desmoronamento de sua estabilidade mental e moral. ${ }^{25}$

Esse é um movimento constante que guia o restante do romance, e que o torna, estruturalmente, tão simples e tão expressivo. Ele ocorre primeiramente no citado episódio da questionável epifania de Werther (carta de 10 de maio), no qual ele termina constatando ter em mãos, como resultado de sua experiência, um mero repositório de impressões fugidias, o qual não o livra de viver os mesmos momentos de inconstância emotiva que, antes de tudo, ocasionaram sua fuga para Wahlheim. A grande ameaça para tal postura de mundo é, por fim, a própria transitoriedade das coisas, uma disparidade incontornável entre a alma humana e o "estatuto substancial do mundo",

\footnotetext{
24 "Mas vou ao chão ante isso, sucumbo ante o poder e majestade dessas aparições" (GoETHE, 2001: 15).

${ }^{25}$ Seguindo uma constante também vista nos dramas do Sturm und Drang, o romance problematiza a real possibilidade de integração do sujeito à sociedade, e deixa seu leitor com uma série de conclusões negativas para tal problemática.
} 
Vale da Silva, Felipe. - Werther à luz da história do conceito de subjetividade

cujos relances ele só pode contemplar de forma fugidia. O mesmo movimento volta a acontecer em episódios que seguem a carta de 22 de maio, dentre os quais isolarei o mais esperado em um romance epistolar: a história de amor por Lotte.

\section{Lotte}

Imbuído de um novo modo de encarar sua missão íntima, Werther rejeita subordinar-se à realidade externa e direciona sua atenção à investigação de algo que lhe é intrínseco. Seu individualismo - em grande medida o único modo de experiência de Werther ressaltado pela maioria da crítica ${ }^{26}$-, assim, é sintomático de um fracasso de integração plena com a natureza. O refúgio naquilo que lhe é intrínseco passa a ser justificado para seu correspondente Wilhelm como 'amostra de seu gênio', ${ }^{27}$ e reação legítima a um mundo social inibidor da 'verdade potencial sobre si' que reside em cada ser humano. Essa é uma afirmação, porém, de uma personagem que já dera claras provas de sua instabilidade emocional e certa inclinação ao escapismo. A vivência do idílio em Wahlheim, em si, traz um caráter estritamente permeado pela fantasia poética: a todo o momento Werther relaciona sua experiência a um repertório de leituras, com um corpus que abrange produções literárias e iconográficas de Homero a Klopstock. As referências intertextuais a esses produtos literários são ocasionais, desprovidas de qualquer rigor interpretativo e suscitadas a fim de estabelecer livres associações a eventos de sua própria vida, conferindo-lhes, assim, a função interpretativa que lhes falta. ${ }^{28}$ O que

\footnotetext{
${ }^{26}$ Ver o vasto balanço de posicionamentos mais pontuais da fortuna crítica da obra em BLACKALL (1976: 280-283). Nesta reconsideração do posicionamento existencial de Werther como uma afiliação unilateral a um individualismo, sou devedor sobretudo de MUENZER (1984: 5) e BLACKALL (1976: 21-27).

${ }^{27}$ Ver carta de 22 de maio (Werther: 22 ).

${ }^{28}$ Nas palavras de WIETHÖLTER (in Goethe 2006: 947): “O mundo de Werther não é nada além de um emaranhado de leituras e recordações visuais, às quais o herói recorre à sua própria maneira, e por isso termina, a recorrer a suas faculdades cognitivas, por identificar a natureza como mera 'imagem pintada' [lackiertes Bildchen], o cenário de sua vida como um baú de raridades e considerar a si próprio como uma marionete controlada por mãos estranhas." (tradução nossa). A estetização traz um caráter paradoxal em função de suas origens na experiência de 'definição de sentido existencial' do protagonista: ela é eleita como forma de acesso holístico à totalidade da criação e dos nexos cósmicos, mas que se encontra sempre medida por discurso, por cultura, enfim. Werther parece se deixar confrontar por essa insuficiência, e logo abandona seu hábito de mencionar o corpus literário genial com o qual se identifica, inicialmente
} 
Vale da Silva, Felipe. - Werther à luz da história do conceito de subjetividade

legitima tal uso da imaginação, por fim, é sua aspiração por autossuficiência que, de antemão, valida o emprego bastante livre de seu sentimento sobre o mundo por ele interpretado. Coerência interna é eleita como valor máximo nessa nova 'tomada de fôlego', digamos, de sua missão de descoberta pessoal.

No momento em que Werther começa a descrever seus encontros com outros indivíduos - algo que ocorre somente a partir da carta de 15 de maio -, ele o faz de forma bastante previsível: habitantes do "mundo da civilização" 29 são relegados a uma categoria geral e previamente desconsiderados como possível companhia para alguém com seu tipo de sensibilidade. Pessoas simples das províncias locais, contudo, são alvo de suas elogiosas descrições. A pureza humana ideal é categoricamente projetada em camponeses, crianças e jovens mulheres, mencionados na qualidade de figurantes do quadro idílico de sua imaginação. Embora atribua simplicidade a essas pessoas, Werther de certa forma se inclui dentro do grupo: "Die geringen Leute des Ortes kennen mich schon und lieben mich, besonders die Kinder" ${ }^{, 30}$.

Essa categoria humana mais autêntica será encarnada na famosa figura de Lotte, o protótipo de moça incauta, afastada dos males do mundo burguês em decorrência de seu caráter livre e origem campesina. Até que Lotte surja na narrativa, os desdobramentos potencialmente negativos da ilusão de Werther permanecem silenciados. Até então ele é livre para projetar quaisquer valores sobre as pessoas, justamente pelo fato de não ter um contato realmente íntimo com elas. É certo que Lotte também será apropriada por seu sentimento; mas quando este 'mecanismo de apropriação' passa a dirigir seu foco para ela, Werther tem que lidar com certas insuficiências do modo de agir da moça. Lotte canalizará a principal crise no romance por um motivo bastante simples: ela não pode ser transformada em personagem de sua fantasia masculina, por força de seu próprio caráter e do autêntico afeto que inspira; ao lidar com ela, ele deve encarar o fato de que a pessoa eleita como alma gêmea é também parte do mundo conservador que lhe causa tanta repugnância

explorado com certa frequência. A partir daí, ele irá encontrar em uma força vital - o amor - novo fundamento e peça expressiva vinculada ao cometimento existencial que inicia o romance.

${ }^{29}$ Em seus termos, "Gesellschaft"“; cf. Werther: 18 (17 de maio).

${ }^{30}$ Werther: 18 (15 de maio). "As pessoas simples do lugar já me conhecem e gostam de mim, sobretudo as crianças" (GOETHE 2001: 17). 
Vale da Silva, Felipe. - Werther à luz da história do conceito de subjetividade

A ocasião do encontro dos dois, descrita na carta de 16 de junho, é um baile para o qual Werther fora convidado por um “Amtmann S...”, pai de Lotte, em uma paragem rural próxima a Wahlheim. Na ocasião, Werther depara-se com várias versões ou facetas de Lotte, o que apenas se acrescenta à impressão de charme e vivacidade da garota. ${ }^{31}$ Há uma ocasião especial, porém, que desencadeará de forma definitiva a amizade entre os dois: Werther encontra em Lotte alguém que compartilha seus interesses pessoais - elegendo-a como uma gleich empfindende Seele ao melhor estilo do Sentimentalismo. Como participantes do mesmo cenário cultural - algo que talvez, no livro, soe críptico para o leitor atual -, Lotte e Werther encetam sua primeira conversa falando dos livros que leem, não propriamente por via de uma identificação direta de si próprios (cf. Id.: 42 e 44; 16 de junho de 1771). O reconhecimento de que há uma concordância na sensibilidade entre as duas partes é crucial na dinâmica de socialização retratada nesse instante do livro. Mas já nesse primeiro instante ocorre uma espécie de falha de comunicação entre o casal de amigos: conforme Lotte fala de seus gostos literários, ela termina por declarar certo repúdio à literatura Sentimental (cf. Id.: 42 e 44), pois já superara este tipo de experiência estética conforme amadurecera, e encontra agora prazer em um tipo de leitura na qual ela pode se deparar com uma exposição mais objetiva do mundo, mundo no qual os eventos ocorrem do mesmo modo que ocorrem ao redor dela (e não dentro dela, na dimensão de sua sentimentalidade: “bey dem's zugeht wie um mich"). Lotte distancia-se do tipo de projeção psicológica do mundo ideal contida na personalidade de Werther. Este, por sua vez, fica declaradamente desconcertado com a asserção da amiga e ignora negligentemente essas palavras, para reconsiderar sua afinidade com a moça no gosto comum dos dois por Klopstock.

Resumamos o episódio que descreve a ocasião de 'reconhecimento de afinidades' entre os amigos: antes que as danças previstas para o evento acabem, iniciase uma violenta tempestade. Vendo que alguns convidados mostram-se desmotivados a continuar no baile e se dispõem a ir embora, Lotte propõe um jogo em grupo como fonte de distração, até que a tempestade passe. Conforme isso acontece, o baile recomeça, e Werther segue a moça até a sala para elogiar sua conduta como anfitriã da festa. Juntos eles contemplam, silenciosos, o fim da tempestade, na cena que se segue:

\footnotetext{
${ }^{31}$ Ibid.: 40 e 42,46 e 48.
} 
Vale da Silva, Felipe. - Werther à luz da história do conceito de subjetividade

Wir traten an's Fenster, es donnerte abseitwärts, und der herrliche Regen säuselte auf das Land [...] Sie stand auf ihren Ellenbogen gestützt, ihr Blick durchdrang die Gegend; sie sah gen Himmel und auf mich, ich sah ihr Auge thränenvoll, sie legte ihre Hand auf die meinige und sagte - Klopstock!

Ich versank in dem Strome von Empfindungen, den sie in dieser Loosung über mich ausgoß. Ich ertrugs nicht, neigte mich auf ihre Hand und küßte sie unter den wonnevollsten Thränen. Und sah nach ihrem Auge wieder - Edler! hättest du deine Vergötterung in diesem Blikke gesehen, und möcht ich nun deinen so oft entweihten Nahmen nie wieder nennen hören $!^{32}$ (Werther: 52 e 54)

Este é um momento de suma importância para o jovem casal de amigos. Ao exclamar “Klopstock!" Lotte remete ao célebre poeta do Sentimentalismo Friedrich Gottlieb Klopstock. A menção tece a analogia a seu poema Frühlingsfeier, no qual uma tempestade é poeticamente descrita não como um mero fenômeno meteorológico, mas como uma reconstituição mítica do ciclo de revivificação natural e, por conseguinte, da manifestação da glória divina. ${ }^{33}$ A reação espontânea da garota expressa sua vivência da tempestade - e, pode-se dizer, da dinâmica natural como um todo - não meramente como correlata a um tema de seu repertório de leituras, mas como um paradigma mítico de acordo com o qual eventos naturais incorporam um significado poético. A visão dessa jovem demonstra interpretar o mundo da mesma forma que Werther, ou seja, potencializando poeticamente seu significado. Lotte é tomada como um Outro equivalente, ou melhor dizendo, como contraparte de Werther; ela supostamente compartilha seu tipo de sensibilidade e busca a experiência de completude que desde o início do livro inquieta o protagonista. Paralelamente a moça porta em si a capacidade de aceitar a vida ordinária de um modo como Werther jamais conseguiria.

Na mesma carta mencionada acima, há uma segunda cena que nos revela importantes dados acerca do tipo de vínculo projetado pelo protagonista na imagem da

\footnotetext{
32 "Trovejava ao longe e uma chuva esplêndida caía sobre a terra em doces murmúrios [...] Ela estava parada, apoiados os cotovelos ao parapeito; seu olhar passeou pela paisagem, elevou-se ao céu e dirigiuse a mim, e vi os seus olhos cheios de lágrimas quando pôs sua mão sobre a minha e disse: 'Klopstock!'. Lembrei-me logo da ode sublime que lhe ocupava o pensamento e mergulhei na torrente de sentimentos que ela derramava sobre mim naquele momento. Não pude suportá-lo, inclinei-me para a sua mão e beijei-a sob o impulso de lágrimas deleitosas, voltando a contemplar os seus olhos em seguida... Nobre poeta! Oh, se tivesses visto tua apoteose naquele olhar! E se eu pudesse não voltar a ouvir jamais teu nome tantas vezes profanado em outros lábios!" (GOETHE 2001: 42-43).

${ }^{33}$ Uma apresentação sugestivamente próxima à experiência de unio mystica descrita no início do romance, na qual eventos singulares do mundo natural remetem a uma dimensão de totalidade, de plenitude de sentido e harmonia incutida na completude da criação.
} 
Vale da Silva, Felipe. - Werther à luz da história do conceito de subjetividade

moça. Werther relata detalhes sobre as danças executadas no baile, e como é bastante previsível, ele pede sua mão para a próxima dança, cujo relato se dá no trecho seguinte:

\begin{abstract}
Nun giengs, und wir ergötzen uns eine Weile an mannchgaltigen Schlingungen der Arme. Mit welchem Reize, mit welcher Flüchtigkeit bewegte sie sich! Und da wir nun gar an's Walzen kamen, und wie die Sphären um einander herumrollten, giengs freylich anfangs, weil's die wenigsten können, ein bisgen bunt durch einander [...] Nie ist mir's so leicht vom Flekke gegangen. Ich war kein Mensch mehr. ${ }^{34}$ (Werther: $48 ; 16$ de junho, meu grifo)
\end{abstract}

O caráter simbólico da cena é interpretado por Géza von Molnár (apud DYE 2004: 88) pela identificação através da qual a corporalidade é sucintamente explorada no texto. Werther é bem específico ao descrever a dança como uma espécie de vertigem - nela, o campo da alteridade corpórea desaparece, "the dancing couple becomes a transfinite body, isolated because unrelated to any alterity, and yet within this isolation total unto itself”. Lotte não é apenas alguém com quem ele se identifica, mas ele encontra também sua integração ideal em um nível forçosamente estético - sua ligação com a amada passa a assumir dimensões místicas outrora buscadas no contato com a natureza e através do 'verdadeiro sentido de seu Eu'. Dessa feita, identificamos no caso amoroso entre Werther e Lotte uma continuidade do motivo da tensão existencial entre sujeito e mundo das primeiras cartas. A confusa sobreposição de ansiedades existenciais e projeções estéticas desassociadas de qualquer referencial objetivo permitem um desenvolvimento da ideia de que o valor da existência pessoal se consumaria em sua união com a moça.

A viabilidade da apropriação de Lotte para si é quase imediatamente colocada em xeque pelos fatos que se seguem na narrativa (carta de 30 de julho). Pouco depois de se convencer de seu amor pela garota, Werther passa a ter que lidar com o fato que ela já possui um noivo, que, no exato momento em que se insere na história, o leva a constatar resignadamente: “Albert ist angekommen, und ich werde gehen",35. O indivíduo pretensamente autossuficiente é destronado pela realidade.

\footnotetext{
34 "E assim começou! Entretivemo-nos a princípio com mil passagens de braços. Com que graça, com que agilidade ela fazia seus movimentos! E quando chegamos à valsa e começamos a girar uns ao redor dos outros como esferas celestes, houve, a princípio, certa confusão, pois poucos pares sabiam dançá-la. [...] nunca me senti tão solto. Já nem mais humano era." (GOETHE 2001: 38-39)

${ }^{35}$ Werther: 84 (30 de julho). "Albert chegou, e eu irei embora" (tradução nossa).
} 
Vale da Silva, Felipe. - Werther à luz da história do conceito de subjetividade

Albert assume aos poucos a imagem de um marido indigno da garota; questionase a autenticidade de seu vínculo afetivo para com Lotte. ${ }^{36}$ Toda problemática reverte para um quadro trágico no qual um grande mal-entendido se instaura na vida dos dois, supostamente destinados a estarem juntos, e separados por forças de uma má sociedade ou por infortúnio do destino. Werther, aqui, transforma Lotte em destino, na única entidade com a qual ele poderia se integrar e se elevar sobre as limitações e transitoriedade da vida. O distanciamento gradual da realidade, da qual essa ideia fixa decorre, é causador da tomada de certas atitudes que, desastrosamente, colocam em jogo a própria amizade entre os dois. Lemos no final do livro uma ocasião em que Werther, já claramente sem controle de suas faculdades mentais, aproveita a ocasião da ausência de Albert para declarar seu amor a Lotte (Id.: 246), ao que ela o repreende veementemente, proibindo-lhe quaisquer visitas futuras. No auge de sua perturbação mental, prestes a suicidar-se, Werther ainda acalenta a ideia de tê-la de "forma espiritual”, e, em um cenário bastante fantasioso, de voltar para buscá-la:

[...] du bist von diesem Augenblikke mein! Mein, o Lotte. Ich gehe voran! Geh zu meinem Vater, zu deinem Vater, dem will ich's klagen, und er wird mich trösten biß du kommst, und ich fliege dir entgegen und fasse dich und bleibe bey dir vor dem Angesichte des Unendlichen in ewigen Umarmungen. ${ }^{37}$ (Werther: 250; 22 de dezembro)

É importante observar certo esforço por parte de Werther em dar fechamento poético para sua vida, justificando seu suicídio como única solução possível de uma conjuntura da qual não se pode fugir. Seu maior fracasso enquanto indivíduo em busca do valor (um valor que ele encontrou, justamente na figura de Lotte, mas falhou em integrá-la à sua vida) é: Werther não pode gerar uma forma de relação com a amada que transcenda suas crises pessoais. Ao contrário, em seu discurso exaltado no final do livro o protagonista 'deixa escapar' o típico narcisismo daqueles que encaram o mundo exterior como catálogo de soluções prontas para suas necessidades pessoais. A imagem final de Lotte $^{38}$ - daquela Lotte que decide recusá-lo como amante - só é concebível na mente

\footnotetext{
${ }^{36}$ Werther: 170 (10 de outubro).

37 "Desse momento em diante, tu foste e serás minha! Minha, oh, Lotte! Sigo adiante! Vou ter com meu Pai, com teu Pai. Queixar-me-ei a ele, e ele haverá de me consolar até a tua chegada, quando voarei ao teu encontro, cingir-te-ei, ficando unido a ti em presença do Eterno, num abraço infinito" (GOETHE 2001: 177).

${ }^{38}$ Que lemos em Werther: 250.
} 
Vale da Silva, Felipe. - Werther à luz da história do conceito de subjetividade

do suicida como a imagem de uma moça resignada, vítima de uma criação moralista, e fantoche do desejo de ascensão social. Ela o repele, em sua mente, em um ato de renúncia, compartilhando sua expiação trágica. ${ }^{39}$ Nisso identifico um sinal crucial de sua falta de consideração pela autonomia de Lotte, este Outro de Werther, paradoxalmente deriva do sentimento de união fraternal sentimental do início do livro.

Em sua carta de despedida, Werther deixa instruções para seu velório e pede a Lotte que conte "a história de seu infortunado amigo" para seus irmãos, de forma a deixar para a posteridade uma imagem de si munida do caráter estético que ele insiste ver em sua jornada. A lógica de seu suicídio, assim, completa-se com esses últimos desejos e vale como último ato de resistência à possibilidade de um fracasso em eventos marcadores de seu projeto de autodefinição. A ameaçadora perspectiva de que realmente faltaria um sentido premeditado para a existência humana é deixada de lado e substituída por uma formulação dramática de que sua vida pessoal se configuraria em descompasso com a ordem vigente do mundo que, à maneira das tragédias tradicionais, deve ser expiada, como em uma história de martírio. Parafraseando MuENZER (1984: 34), o suicídio resulta como um último gesto que dá forma à relação de Werther com uma lei supostamente superior (e inquestionada) de autonomia pessoal.

Nossa reconstrução de posturas existenciais pontuais assumidas por Werther assim como o vínculo causal e simbólico que estabeleceria em sua relação com Lotte permite abrir a perspectiva de que o suicídio retratado no livro não vale como consequência do fracasso amoroso em si. É possível retraçar as origens de uma disposição anímica que tenderia ao desfecho suicida, para sermos mais exatos, na problemática inicial do livro: nas pretensões por totalidade e na dissolução da individuação.

É coerente afirmarmos que a tensão lentamente construída na narrativa pensemos aqui no leitor sentimental que lia o texto pela primeira vez - ganha em intensidade já que, conforme o texto avança, parece cada vez mais improvável que Werther se livre de suas complicações, seja acolhido por um destino favorável e finalmente encontre um lugar no mundo. É esse o desfecho esperado dentro do contrato

\footnotetext{
${ }^{39}$ Aqui é significativo que a pessoa de quem Werther recebe a arma (emprestada!) de seu suicídio seja a própria Lotte; ver ibid.: 258: "O criado chegou com as pistolas à casa de Werther, que tirou-lhas das mãos encantado quando soube que fora Lotte quem as havia dado"(cf. GOETHE 2001: 182).
} 
Vale da Silva, Felipe. - Werther à luz da história do conceito de subjetividade

ficcional ‘emprestado' por Goethe, pressuposto instaurado em sua relação de autor com seu leitor histórico. Por outro lado, quando chegamos à cena do suicídio, não podemos negar que há de fato um fechamento estético no romance - e a aniquilação de Werther estaria claramente insinuada nele desde o início ${ }^{40}$. O próprio autor nos provê elementos antecipadores desse desfecho em seu uso de imagens - a exemplo da estranha inclinação do jovem pela ideia de livrar-se do fardo do principium individuationis, tratada neste artigo no relato de sua epifania em meio à natureza (ponto 6) e na cena da dança com Lotte (ponto 7). Dessa forma, embora o desfecho do livro frustre o horizonte de expectativas do típico 'rococó cultural' da época, ele não peca em momento algum por falta de verossimilhança.

Werther é verossímil ${ }^{41}$ na medida em que reproduz fielmente as tendências comportamentais e inseguranças de um personagem verdadeiramente digno do universo ficcional do Sentimentalismo. O que não ocorre no universo ficcional inaugurado por Goethe é a presença de uma Providência que opere em favor da personagem. Nesse quesito ele talvez seja mais verossímil, ou realista, do que a fantasia poética de um Richardson, por exemplo, poderia conceber. Parte de seu problema existencial é, justamente, a resignada recorrência a um tipo inofensivo de fantasia poética para resolver o problema da pauperização do sentido da vida. Nesse aspecto crucial, eu argumento, Goethe estaria trazendo a juízo o tipo de dinâmica de leitura do Sentimentalismo - e, claro, o ideário por trás dela - perante um público compartilhador das fragilidades de seu protagonista, que é convidado a partilhar sua história tanto reflexivamente quanto na chave da identificação (como visto no prólogo do romance, ponto 4$)$.

Embora eu identifique uma crítica de visões de mundo no romance, devemos nos questionar, como sugere MUENZER (1984: 6-7), se, ao dramatizar o dilema da aspiração humana por sentido existencial, esse encadeamento de fracassos não transcenderia motivos hagiológicos e didáticos - como se Goethe estivesse interessado em difamar certas posturas de vida - e retratasse o indivíduo sofredor como alguém distinto de uma vítima direta da sociedade ou de certos sistemas de valores. Essas pretensões,

\footnotetext{
${ }^{40}$ Cf. Werther: 98 e 108 (cartas de 12 e 22 de agosto); traduções em GoETHE (2001: 73 e 81).

41 "Werther muß - muß sein!", como formulou Goethe em sua famosa carta a Kestner (21/11/1774) (apud Werther: 927).
} 
Vale da Silva, Felipe. - Werther à luz da história do conceito de subjetividade

entretanto, são negadas pelo autor como parte da diferenciação de seu uso do romance perante os romances tradicionais de sua contemporaneidade. Werther pode assumir ser vítima desfavorecida de um mundo social coercitivo que o circunda, mas a cadência da narrativa não nos permite ver o mundo social agindo diretamente sobre ele. O universo que o circunda - e isso parece intensificar-se no tom alienante de sua experiência de vida - é amorfo, que não age, mas atua como um universo estático que lá se encontra desde sempre, com suas forças sociais e regras caducas, e que continuará imperativo após sua morte. Não há ninguém para ser culpado senão as circunstâncias (e.g. uma força destituída de face tão abstrata quanto as que guiam suas aspirações metafísicas por totalidade, diga-se de passagem).

A formulação goethiana do problema da subjetividade em lugar de expressar a realidade deste sujeito autodefinidor da modernidade - plenamente responsável por seu destino - propõe uma conjuntura social e psicológica avessa a um juízo de valores disponíveis, à harmonização forçada dos autores tradicionais de romance epistolar como Gellert e Richardson. No universo ficcional proposto, o indivíduo não atinge a conciliação com seu meio, sua tragédia termina sem fechamento com um sentido moral, sem um princípio de Bem e Mal. A busca pelo valor individual é fruto de um projeto inédito da Modernidade, ainda a ser elaborado, e que não pode se basear em nenhum edifício cultural disponível - sobretudo nos princípios do individualismo burguês incipiente da cultura popular de então.

Penso em como o esforço por pensar uma cultura de valores da vida na modernidade termina por ocupar a obra posterior de Goethe até 1829 - nos romances seguintes, ao menos, o tratamento da vida do sujeito perde nuances trágicas para recair quase exclusivamente na discussão acerca de novas formas de sociabilidade - pensemos na questão da socialização de Wilhelm Meister como determinação de sua maturidade (para além das barreiras de classe e carreiras profissionais), no Entsagungsideal de Unterhaltungen deutscher Ausgewanderten e de Wilhelm Meisters Wanderjahre. É em vistas, também, deste esforço do Goethe maduro sobre uma formulação de saídas possíveis do tipo de individualismo anulador de Werther que proponho a leitura de uma continuidade presente em seus romances e Werther como ponto de partida de tal projeto estético inovador, responsável pela justa proeminência do autor como criador de novos usos da prosa literária no final do século XVIII. 
Vale da Silva, Felipe. - Werther à luz da história do conceito de subjetividade

\section{Referências bibliográficas}

BECKER, Eva. Der Deutsche Roman um 1780. Stuttgart, J.B.Metzlersche, 1964.

BlacKall, E. A. Goethe and the Novel. Ithaca/London, Cornell University Press, 1976.

BLANCKENBURG, Friedrich von. Rezension: Die Leiden des jungen Werthers (1774) in: WeBER, Ernst (hrsg.). Texte zur Romantheorie II. München, 1981, 392-441.

BoYle, Nicholas. Goethe: The Poet and the Age: Volume I: The Poetry of Desire (1749-1790). Oxford, Oxford University Press, 1991.

BREITHAUPT, Fritz. Goethe and the Self. In: Goethe Yearbook (XI) / Edited by Simon J. Richter. Rochester: Camden House, 2002, 77-100.

Duncan, Bruce. Lovers, Parricides and Highwaymen: Aspects of Sturm und Drang Drama. Columbia: Camden House, 1999.

DYE, Ellis. Love and Death in Goethe. Rochester: Camden House, 2004.

FIORIN, José Luiz. Linguagem e Interdisciplinaridade. In: Alea. Volume 10 (1), Janeiro-Junho de 2008, 29-53.

Foucault, Michel. The Order of Things: An Archeology of the Human Sciences. New York: Random House Inc., 1970.

GELLERT, Christian Fürchtegott. "Briefe, nebst einer praktischen Abhandlung von dem guten Geschmacke in Briefen". In: Gesammelte Schriften. Kritische, kommentierte Ausgabe. Hrsg. von Bernd Witte. Band IV. Berlin/New York, 1989, 105-221.

GoETHE, Johann Wolfgang. Die Leiden des jungen Werthers - Die Wahlverwandtschaften Kleine Prosa - Epen. Hrsg. von Waltraud Wiethölter. Frankfurt am Main: Deutscher Klassiker Verlag, 2006.

GoETHE, Johann Wolfgang. Os Sofrimentos do Jovem Werther (trad. Marcelo Backes). Porto Alegre: L\&PM Editores, 2001.

Habermas, Jürgen. Mudança Estrutural da Esfera Pública. Trad. Flávio R. Klothe. Rio de Janeiro: Tempo Brasileiro, 2003.

HAUSER, Arnold. História Social da Arte e Literatura. São Paulo, Martins Fontes, 2000.

KUEHN, Manfred. The German Aufklärung and British philosophy. In: BROWN, Stuart (ed.). Routledge History of Philosophy, Volume 5: British Philosophy and the Age of Enlightenment. London \& New York: Routledge, 1996, 253-272.

LÚKACS, Györg. Goethe and His Age. London: Merlin Press , 1968.

MANN, Thomas. Goethe's Werther. in: Gesammelte Werke, Band 9. Frankfurt-am-Main: Fischer, 1960.

Matos, Franklin. O Solilóquio de Werther. In: Werle, M. A. \& Galé, P. F. Arte e Filosofia no Idealismo Alemão. São Paulo: Editora Barcarolla, 2009, 141-150.

Mattenklott, Gert. Die Leiden des jungen Werthers. In: Witte, Bernd; SchmidT, Peter. Goethe Handbuch, Band 3. Stuttgart \& Weimar: J.B. Metzler, 2004, 51-101.

MCKEON, Michael. Theory of the Novel: A Historical Approach. Baltimore \& London: The Johns Hopkins University Press, 2000.

MUENZER, Clark S. Figures of Identity: Goethe's Novels and the Enigmatic Self. University Park and London: The Pennsylvania State University Press, 1984. 
Vale da Silva, Felipe. - Werther à luz da história do conceito de subjetividade

SAUDER, Gerhard. Empfindsamkeit. In: DAHNKe, Hans-Dietrich; OTTO, Regine. Goethe Handbuch, Band 4/1. Stuttgart \& Weimar: J.B. Metzler, 2004, 248-252.

SLOTERDIJK, Peter. Weltfremdheit. Frankfurt-am-Main: Suhrkamp Verlag, 1993.

Swales, Martin \& SwaLeS, Erika. Reading Goethe: A Critical Introduction to the Literary Work. Rochester, Camden House, 2002.

Swales, Martin. Goethe's prose fiction. in: SHARPE, Lesley (ed.). The Cambridge Companion to Goethe. New York: Cambridge University Press, 2002, 129-146.

VALE DA SILVA, Felipe. Subjetividade e Experiência em Die Leiden des jungen Werthers e Wilhelm Meisters theatralische Sendung de J. W. Goethe. Dissertação de Mestrado. Universidade de São Paulo, São Paulo, 2012. Disponível em: http://www.teses.usp.br/teses/disponiveis/8/8144/tde-06122012-145632/pt-br.php (último acesso em 18/06/2013)

VAN DÜLMEN, Richard. Religion, Magie, Aufklärung: 16.-18. Jahrhundert. München: C. H. Beck Verlag, 2005. 